\title{
Youths' Perception of the Impact of Inter and Intra Ethnic Conflicts on Socio-economic Development in Delta State, Nigeria
}

\author{
Ajayi, A. R., Akinnagbe O. M. and Aghojare T \\ Department of Agricultural Extension \\ University of Nigeria, Nsukka \\ Corresponding e-mail:wolexakins@yahoo.com
}

\begin{abstract}
The study was undertaken to determine youth's perception of the impact of ethnic conflicts on socio-economic development in Delta state. Data for the study were collected from 102 youths from ljaw, Itsekiri and Urhobo through the use of structured questionnaire. Percentage and mean scores were used in the data analysis. The results of the study indicated that unevenly distribution of compensations from government (91.2\%) and unevenly sharing of resources (81.4\%) were the most important causes of ethnic conflicts in the area. It was also revealed that unemployment $(\bar{X}=1.65)$ and poverty $(\bar{x}=1.46)$ were the major factors influencing youth's participation in ethnic conflicts. The impact of the conflicts was most severe on human lives ( $\bar{x}=2.42$ ) and buildings ( $\bar{x}=2.13)$. It was recommended that the Delta state government through the Agricultural Development Programme (DSADP) should embark on virile community and school rural youth extension activities such as young farmers' clubs programme.
\end{abstract}

Keywords: Youth, Ethnic conflict, socio-economic development

\section{INTRODUCTION}

Conflict in whatever form is often an uncomfortable and energy consuming experience. Mayer (2005) opined that conflict is an emotional reaction to a situation or interaction that signals disagreement of some kind. The emotion felt might be fear, sadness, bitterness, anger or hopelessness. According to Oke (2000); conflict is an incompatible feeling between groups or people. Conflict may also be described as an open clash between two opposing groups or individuals. Conflict may be described as war, battle, and struggle, opposing ideas or disagreement or quarrel between individuals.

Adidi (2005), posited that conflict might arise due to different causes such as land ownership, ethnic rivalry, overgrazing, land boundaries religious differences and unequal distribution of government resources. Whatever the cause of conflict, usually has a devastating effects on the people involved; the children, youths, women men, and even the environment. Conflict may lead to loss of life, properties, destruction of infrastructural facilities such as electricity, houses, and water pipe lines, destruction of crops and even live stocks.

Conflicts are of different types. Asaju (2000), classified conflict in rural community into four groups; these are intra-personal conflicts, inter personal conflict, intra group conflicts and inter group conflicts. Intra-personal conflict is that which falls within a person and is caused by 
being pushed into two or more directions at once. For instance when opinion leaders within the rural community delegate responsibility to their subordinate, they often create intra-personal conflict by expecting too much from the subordinate. This is conflict within the person. Interpersonal conflict involves strains between two or more people in an organisation or society (Asaju 2000). It has to do with two or more individuals arguing over different goals or values task assignments in the society. Ademuyiwa (1999) discovered that in Nigeria, a person-toperson or individual conflict is among the communist form of conflicts. Intra-group conflicts are that type of conflicts that often occurs between sub-groups, factions and communities, formed within a group (Asaju 2000). Sole (2003) observed that inter-group conflict exist between two different groups in the form of competition. This kind of conflict can be over assignment of responsibility, limited resources or as a result of status.

The inter-ethnic conflicts in Delta State have been between the ljaw's and the Itsekiri's on one hand and between the Itsekiri's and Urhobo's on the other. Within each of these groups, we have also witnessed intra-ethnic conflicts. In Delta State, like many other States in Nigeria, Bolarinwa, (2006), reported that the prevailing worrisome violent conflicts in many rural communities have distorted the normal livelihood of many farmers and their families. Women farmers and their children for instance, are no more regular at their farms to carry out normal agronomic activities because of fear. Majority of farmers no longer cultivate their distant scattered farmlands. They are virtually almost restricted to their compounds and short distant farmlands. Restriction on movement has limited access to essential farm inputs such as improved seeds, fertilizers and credits. Many farm households could not easily market their farm produce (Nonli, 1989).

Apart from the forging, both intra and inter ethnic conflicts have had a lot of devastating effects on employment, health, political, religion, industrial, educational and local institutional development activities in the study area. In addition, if and whenever violence erupted, both private and government buildings and other valuable properties are often targeted and destroyed (Nonli, 1989).

According to Emme and Emme (1997), traders at the various market centers at Warri also had a share of the negative impact of the conflicts. In April 1997, several market goods were either looted or set ablaze. The most affected markets were the Warri main market, Pessu and Okere. Many of the traders could not get back to the markets to continue with their trading because they could not raise enough money to start off again. Many traders left Warri for other locations because of fear of further destructions. Apart from parlaysing business activities, lives and properties also suffered colossal loss.

In each of these conflicts, the youth were always very much involved. Youth are boys and girls who are within the age range of 15 to 30 years. It is a period of life between childhood and adulthood. The youth of today are the future farmers and farmers' wives. They are the feature of economic, political, industrial, agricultural and educational development of any nation (Ajayi, 2006).

The pertinent question at this juncture relates to the youth's perception of the impact of both intra and inter ethnic conflicts on the socioeconomic development in their communities and their perceived strategies to curb them. What is the youth's perception of the impact of inter and intra ethnic conflicts on the socioeconomic development of their communities and how do they think that such conflicts could be curbed? 
Journal of Agricultural Extension

Vol. 13 (2) December 2009

\section{Purpose and Objectives}

The purpose of the study was to determine the youth's perception of the impact of inter and intra ethnic conflicts on socio-economic development in Delta state, Nigeria. Specifically the study was designed to:

1. determine the youth's perceptions of the major causes of inter and intra ethnic conflicts in the study area;

2. find out the perceived factors influencing youth's participation in inter and intra ethnic conflicts in the study area;

3. determine the impacts of inter and intra ethnic conflicts on socio-economic development in the study area; and

4. determine the youth's perceived strategies for curbing future re-occurrence of inter and intra ethnic conflicts in the study area.

\section{METHODOLOGY}

The study was carried out in Delta state. The target populations of the study were the youths from, ljaw, Itsekiri and Urhobo ethnic groups in Delta State. Three local government areas (Warri North, Warri South and Warri South West) were purposively selected from the 25 local government areas in the State because of frequent re-occurrence of conflicts in them. From each of the 3 local government areas, two communities were randomly selected through the use of simple random sampling technique. This made a total of 6 communities. From each of the 6 communities, 17 respondents were selected through simple random sampling technique from a list of 30 youth per community. Hence, 102 respondents from a population of 180 youths were selected.

Data for the study were collected from the respondents through the use of questionnaire schedule. Youth perceptions of the major causes of inter and intra ethnic conflicts were measured by assigning 1 if yes, and 0 if no to indicate if they have experience conflict in the area. The respondents were also asked to indicate the type of conflicts they had witnessed, and their responses were categorized as inter ethnic conflicts $=1$, intra ethnic conflicts $=2$ while the major causes of inter and intra ethnic conflicts were measured on a 2-point Likert-type scale of 1 for minor and 2 for major.

To determine respondents perceived factors influencing youth's participation in inter and intra ethnic conflicts, a 3- point Likert - type scale of no extent $=0$; to some extent $=1$; and to a greater extent $=2$ was used. The values on the Likert-type scale were summated to 3 , which were later divided by three, to get a mean score of 1.0 . The respondents' mean scores were obtained for each response item such that any one higher or equal to 1.0 was regarded as important factor influencing youth is participation in conflicts while while mean score less than 1 was regarded as not important factor.

To determine the impact of inter and intra ethnic conflicts on socio-economic development, the respondents were asked to rate some perceived impacts, of inter intra ethnic conflict on a 5 point Likert - type scale of very severe $=4$, severe $=3$ mildly severe $=2$, Not severe $=1$ and No damage $=0$. The values on the Likert-type scale were summated to 10 , which were later divided by four, to get a mean score of 2.0. The respondents' mean scores were obtained for each response item such that any one higher or equal to 2.0 was regarded as very important to cause damage on the socio-economic development, while mean scores below 2.0 were regarded as not important to cause damage in socio-economic development. 
To determine youth perceived strategies for curbing future re-occurrence of inter and intra ethnic conflicts, the respondents were asked to indicate their level of agreement on each of the strategies provided on a 4 - point Likert - type scale of strongly agreed - 3; Agreed = 2; Disagreed $=1$; and strongly disagreed $=0$. The respondents' mean scores were obtained for each response item such that any one higher or equal to 2.0 was regarded as very important factor for curbing future re-occurrence of conflicts, while mean score less than 2 was regarded as not important factors.

Percentage and mean scores were used to summarized the data. The "statistical package for the social science" (SPSS 11) constitutes the software packages used for the analysis.

\section{RESULTS AND DISCUSSION}

\section{Causes of inter and intra ethnic conflicts in Delta State}

Table 1 reveals that unevenly distribution of compensation from government/oil companies $(91.2 \%)$, unevenly sharing of resources $(81.4 \%)$, accidental killing of a community member $(72.4 \%)$, desire for autonomous community $(68.6 \%)$, unevenly sharing of political power/position $(61.8 \%)$, government involvement in a negative way $(61.8 \%)$, political rivalry $(57.8 \%)$, relocation of local government area headquarter $(64.7 \%)$, land acrimony $(65.7 \%)$ and wrongly sitting of an educational institution (56.8\%), were perceived by the youth to be the major causes of inter and intra ethnic conflicts in the area. The implication of these findings is that unevenly distribution of compensation and uneven sharing of resources are most important factors causing conflicts in the area.

TABLE 1: Percentage distribution of youth based on the major causes of inter and intra ethnic conflicts

\begin{tabular}{lcc}
\hline \multicolumn{1}{c}{ Causes } & Frequency & (\%) \\
\hline Desire for autonomous community & 70 & 68.8 \\
Sitting of an educational institution & 58 & 56.9 \\
Selfishness of the leaders & 65 & 63.7 \\
Location of local government area (head quarter) & 66 & 64.7 \\
Unevenly distribution of compensation from & 93 & 91.2 \\
Government loil companies & & \\
Unevenly sharing of resource & 83 & 61.4 \\
Land acrimony & 67 & 44.1 \\
Domineering attitude of certain communities & 45 & 36.3 \\
Chieftaincy title & 37 & 32.4 \\
Religious differences & 33 & 61.8 \\
Unevenly sharing of political powers & 63 & 57.8 \\
Political rivalry & 59 & 72.5 \\
Accidental killing of a community member & 74 & 61.8 \\
The government involvement in a negative way & 63 & \\
\hline
\end{tabular}

${ }^{*}$ Multiple responses. 
Journal of Agricultural Extension

Vol. 13 (2) December 2009

\section{Perceived Factors Influencing Youth's Participating in Inter and Intra Ethnic Conflicts}

Data in Table 2 show that unemployment $(x=1.65$ SD 0.539$)$; poverty $(x=1.46, S D=$ $0.624)$, lack of adequate information $(x=1.4, S D=0.649)$; lack of formal education $(x=1.38$, $S D=0.661)$; lack of parental care $(x=1.37, S D=0.612)$; readily availability of weapons $(x=$ $1.28, S D=0.695)$; and the quest to have fighting weapon $(x=1.23, S D=0.730)$ were perceived important factors influencing youth's participation.

Table 2 also shows that family influence $(x=0.72, S D=0.680)$; religion $(x=0.78, S D=$ $0.698)$; encouragement from the traditional leaders $(x=0.89, S D=0.782)$; and self ego $(x=$ $0.89, \mathrm{SD}=0.782$ ) were perceived as less important factors influencing youth's participation in inter and intra ethnic conflicts. One of the major importances of the findings is that a greater proportion of the youths were unemployed. This is in agreement with the study on African conflicts (1991) which show that majority of those actively engage in ethnic conflict are the unemployed and jobless youth with low per capital income backgrounds.

TABLE 2: Mean distribution of respondents based on the perceived factors influencing their participating in inter and intra ethnic conflicts $(n=102)$

\begin{tabular}{lcc}
\hline \multicolumn{1}{c}{ Variables } & Mean & Standard \\
& $(\mathrm{X})$ & $\begin{array}{c}\text { deviation } \\
\text { (SD) }\end{array}$ \\
\hline & & \\
Ignorance/lack of adequate information & 1.4 & 0.649 \\
Poverty & 1.46 & 0.624 \\
Unemployment & 1.65 & 0.593 \\
Peer group influence & 1.03 & 0.652 \\
Lack of formal education & 1.38 & 0.661 \\
Religion & 0.78 & 0.698 \\
Encouragement from traditional leaders & 0.89 & 0.782 \\
Family influence & 0.72 & 0.680 \\
Encouragement from politicians & 1.16 & 0.671 \\
Self ego (showing off) & 0.89 & 0.782 \\
Lack of parental care & 1.37 & 0.612 \\
Readily availability of weapons & 1.28 & 0.695 \\
The request to have fighting and use of weapon experience & 1.23 & 0.730 \\
\hline
\end{tabular}

\section{Impact of Inter and Intra Ethnic Conflicts on the Socio-Economic Development of the Study Area}

The data on Table 3, reveal that loss of lives $(x=2.42, S D=0.763)$ and destruction of buildings $(x=2.13$, SD $=0.817)$ were perceived to be the most important impact of inter and intra ethnic conflicts on socio-economic development. Other impact of the conflicts that were not too severe included destruction of normal economic activities $(x=1.89, S D=0.819)$, disruption of educational net work/normal educational activities (lack of conducive teaching-learning processes) with $(x=1.51, S D=1.014)$. From the findings above, it could be concluded that the impact of the conflicts were mostly felt in the area of loss of lives. 
TABLE 3: Distribution of respondents based on their perceived impact of inter and intra ethnic conflicts on socio-economic development $(n=102)$

\section{Perceived impact}

\section{$\operatorname{Mean}(\bar{X})$ \\ Standard \\ Deviation}

(SD)

Loss of lives

2.42

0.763

Destruction of buildings

2.13

0.817

Disruption of normal economic activities

1.89

0.819

Destruction of vehicles

1.75

1.050

1.74

1.014

Disruption of educational network/normal educational
activities (lack of conducive learning teaching processes)

Destruction of markets

1.56

1.131

Disruption of farmers livelihood

1.55

1.140

Poor farming activities

1.51

0.982

Destruction of health care facilities

1.48

1.25
1.069

1.132

\section{Suggested Strategies for Curbing Youth's Inter and Intra Ethnic Conflicts.}

Table 4 shows that provision of formal education $(x=2.67, S D=0.603)$ and provision of employments $(x=2.59, S D=0.650)$ were the major strategies for curbing intra and inter ethnic conflict. Other perceived important strategies for curbing inter and intra ethnic conflicts included equitable allocation of resources $(x=2.44, S D=0.815)$; proper up-brining of a child $(x=2.41$, $S D=0.800)$; equitable distribution of political power/positions $(x=2.34, S D=0.814)$; dialoguing $(x=2.34, S D=0.830)$, empowerment of the youth by (NDE/Oil companies) $(x=2.13, S D=$ $0.804)$.

The implications of these findings are that, provision of formal education and employments would play a significant role in curbing ethnic conflicts in the study area. Ensuring peace in a community lies in the education of members of the community, equitable resources distribution and fulfillment of all human right. 
Journal of Agricultural Extension

Vol. 13 (2) December 2009

TABLE 4: Mean distribution of respondents based on their perceived strategies for curbing inter and intra ethnic conflicts. $(n=102)$

Variable
Mean (X)
Standard Deviation

(SD)
Provision of formal education

Provision of employment to the youth

Sanctions from the government

Sanctions from the community

Empowerment of the youth (NDE/oil company)

Proper up bringing of children by parents

Self determination

Religious intervention

Campaign by the government/NGOs against Inter and intra ethnic conflicts

Dialogue

Equitable distribution of political/position

Equitable allocation of resources

Refusal of peer group influence
2.67

0.603

2.59

0.650

1.84

0.909

1.78

0.951

2.24

0.846

2.41

2.13

0.800

1.81

2.07

0.804

2.30

2.34

2.44

1.79
0.909

0.936

0.830

0.814

0.815

0.762

\section{CONCLUSION AND RECOMMENDATIONS}

The overall purpose of the study was to determine youth's perceptions of the impact of inter and intra ethnic conflicts on socio-economic development in Delta State. The results of the study showed that unevenly distribution of compensations from government and unevenly sharing of resources were the most important causes of ethnic conflicts in the area. It was also revealed that unemployment and poverty were the major factors influencing youth's participation in ethnic conflicts. The impact of the conflicts was most severe on human lives and buildings. It was recommended that the Delta State government through the Agricultural Development Programme (DSADP) should embark on virile community and school rural youth extension activities such as young farmers' clubs programme. 


\section{REFERENCES}

Ademuyiwa, A. A. (1999). Ecological and environmental correlates of communal conflicts in oil mineral producing area of Niger Delta. M.A. Project. Institutes of Ibadan African studies University of Ibadan, Ibadan Nigeria.

Adidi, G. T. (2005). Conflicts resolution strategies among agro-pastora lists and arable crop farmers in Saki-West Local Government Area of Oyo State. An unpublished B.Sc. thesis, University of Ibadan, Ibadan, Nigeria.

Ajayi, A.R. (2006). A guide for young farmers' clubs programme. Akure: SAC Impressions

Asaju, A.S. (2000). Managing conflicts in a developing society. The case of Nigeria in Conflicts Management Strategies to Conflicts Resolution. DEMYAXS Nigeria Ltd. Ibadan.

Bolariwa, K..K.(2006). Assessment of farmer's livelihood in conflict and non conflict areas of Osun and Taraba Statses, Nigeria .A Ph.D. thesis, University of Ibadan, Nigeria. Pp 1222.

Emme, A.. Emme, .O. "Warri latest Volko town set ablaze with explosive" Vanguard, Friday $25^{\text {th }}$ May 1997. pp1

Mayer, E. D. (2005). Nature and impact of African conflicts, Uganda. Retrieved http:// www.en.wikipedia.org.

Nnoli, O. (1989) Ethnic conflicts in Africa Dakari; Senegal CODESRIA. Pp25

Oke, G.O (2000). Traditional system of conflicts resolution. In conflict Management Techniques and Alternatives Strategies to Conflict Resolution.DEMYAXS Nigeria Itd, Ibadan.

Sole, G.A (2003) Psychological approach to prevention and management of conflicts: The Nigeria experience. In Harunah HB, Nwolise B.C, and Kusa D.O (2003).A Guide to Peace Education and Peace Promotion Strategies in Africa. Perfect printers limited 93A, Opebi road Lagos. Pp115-198. 